\title{
ПОСТРОЕНИЕ ГЕОЛОГИЧЕСКОЙ МОДЕЛИ НИЖНЕПЕРМСКИХ КАРБОНАТНЫХ ОТЛОЖЕНИЙ С ИСПОЛЬЗОВАНИЕМ ДЕТЕРМИНИСТИЧЕСКИХ И СТОХАСТИЧЕСКИХ ИНВЕРСИЙ (НА ПРИМЕРЕ МЕСТОРОЖДЕНИЙ ТИМАНО-ПЕЧОРСКОЙ ПРОВИНЦИИ)
}

Макарова Л.В. *, Родина О.А. *, Крук П.Н. *, Зверева Н.В. *, Неудачин Д.Ю. **

("Fugro-Jason, ** OAO «Печоранефть»)

Уникальные технологии компания FugroJason, включающие детерминистические и стохастические инверсии сейсмических данных, позволяют получить детальные количественные характеристики продуктивных интервалов разреза.

Прогноз распределения литологических типов и пористости рассматривается в данной работе на примере месторождений Тимано-Печорской нефтегазоносной провинции.

Территория исследований включает поднятия Лекхарьягинское и Северо-Харьягинское, расположенные в центральной части Колвинского мегавала. Наибольший поисковый интерес представляет толща карбонатньгх отложений раннепермского возраста (ассельско-сакмарские и артинские залежи). Ассельско-сакмарские отложения представлены органогенно-детритовыми, водорослевыми и органогенными, в том числе биогермными известняками, накапливавшимися в условиях мелководного шельфа. В то время как артинские терригеннокарбонатные отложения характеризовались относительно более глубоководными условиями осадконакопиения.

Первый этап исследований включал проведение детерминистической инверсии с ограничениями типа «редких импульсов» (CSSI) (программный пакет компании Fugro-Jason InverTrace ${ }^{\text {plus) }}$, по результатам которой уточнялась морфология резервуара. Разрешенность полученного куба акустического импеданса по вертикали не достаточна для детальной характеристики коллекторских свойств и отражает осредненную характеристику всего нижнепермского карбонатного интервала. Однако, абсолютные значения акустического импеданса откалиброваны по реальным скважинным данным. В связи с чем результаты детерминистической инверсии использовались для прогноза изменения свойств резервуара по латерали. Таким образом, была обозначена тенденция улучшения фильтрационно-емкостных свойств пород-коллекторов на участках, приуроченных к палеоподнятиям. Палеонтологические исследования (данные ООО «Нефтегазгеосервис») подтверждают отсутствие в ряде скважин Лекхарьягинской площади сакмарских отложений, что свидетельствует о наличии на гранище ассельско-сакмарских и артинских отложений перерыва (размыва?) осадконакопления длительностью в несколько миллионов лет. Процессы вышелачивания, происходившие наиболее интенсивно на относительно приподнятых участках, привели к формированию здесь лучших коллекторских свойств (вторичной емкости, в том числе кавернозности).

Следующий этап работ закпючался в проведении стохастической AVA инверсии (программный пакет компании Fugro-Jason RockMod). Анализ керна и данных ГИС позволил выделить литотипы, по которьп далее происходило моделирование упругих свойств пород. Полученная модель строения резервуара максимально опирается на сейсмические данные, сохраняя при этом все статистические зависимости свойств пород, рассчитанные по скважинам, тто позволяет получить как наиболее достоверный результат, так и максимальную разрешенность. В итоге были получены кубы распределения литотипов, типов коллектора, пористости. При этом обособились зоны улучшенных коллекторских свойств, контролируемых палеорельефом дна бассейна седиментация.

Детальные результаты детерминистических и стохастических инверсий позволили провести количественную оценку коллекторских свойств резервуаров, получены детальные геологические модели месторождений, с учетом всей имеющейся геологической и геофизической информации (керн, ГИС, испытания, сейсмика). Прослежены зоны улугшенных коллекторских свойств, контролируемые фациальными, а также постседиментационными гипергенными изменениями.

По результатам комплексного анализа даны рекомендации по планированию буровых работ.

ЛИTEPATYPA:

1) Отчет «Подтотовка программы поисково-разведочныгх работ на Лекхарьягинском лицензионном участке». ООО "Нефтегазгеосервис». Ухта, 2006 